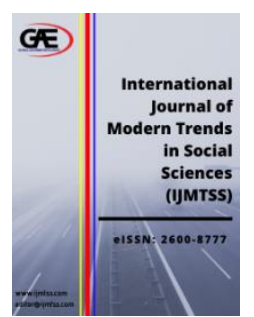

\author{
INTERNATIONAL JOURNAL OF \\ MODERN TRENDS IN \\ SOCIAL SCIENCES \\ (IJMTSS) \\ wWw.ijmtss.com
}

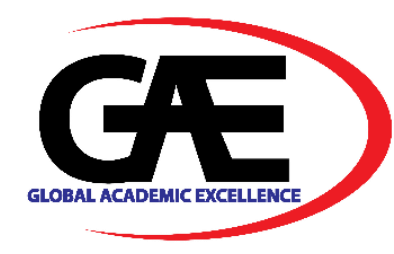

\title{
THE 2020 FRANCE ATTACKS: A FRAMING ANALYSIS OF U.K. AND U.S. NEWSPAPERS
}

\author{
Nur Izzati Ariffin ${ }^{1 *}$, Faridah Hussain ${ }^{2}$ \\ 1 Department of Communication, International Islamic University Malaysia, Malaysia \\ Email: i.ariffin@live.iium.edu.my \\ 2 Faculty of Law, Universiti Teknologi MARA, Malaysia \\ Email: faridah355@uitm.edu.my \\ * Corresponding Author
}

\section{Article Info:}

Article history:

Received date: 03.02.2021

Revised date: 21.03 .2021

Accepted date: 30.03 .2021

Published date: 31.03 .2021

\section{To cite this document:}

Ariffin, N. I., \& Hussain, F. (2021). The 2020 France Attacks: A Framing Analysis of U.K. and U.S. Newspapers. International Journal of Modern Trends in Social Sciences, 4 (15), 133-146.

DOI: $10.35631 /$ IJMTSS.4150012

This work is licensed under $\underline{\text { CC BY } 4.0}$

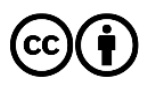

\begin{abstract}
:
The 2020 France attack regarding the controversial issue of the public portrayal of Prophet Muhammad's caricature had created havoc all over the world. This research focuses on how the 2020 France attacks-related issues were portrayed in the media in the United Kingdom (U.K.) and the United States (U.S.). This analysis aims to determine the dominant issues covered, the news slant, and the newspapers' tone and framing regarding the 2020 France attacks-related issues. Using content analysis, the data from news articles and feature articles collected from two mainstream online daily newspapers, which were The Independent from the U.K. and The New York Times from the U.S. were examined. This study also aims to compare the differences between the U.K. and U.S. media in framing and reporting the 2020 France attacks-related issues. A total of 56 news articles were analysed, from which three major issues were reported in the newspapers during that period. The most frequently reported issue was the Islamist 'Terrorism' in France issue. The findings of the study indicated that the news slant of both newspapers was significantly different. The Independent's news slant was balanced towards both France and Islam, while The New York Times' news slant was against Islam.
\end{abstract}

Keywords:

Framing Theory, France Attack, Freedom Of Speech, Media Portrayal Of Islam, Prophet Muhammad's Caricature, Terrorism

\section{Introduction}

On October 16 2020, Samuel Paty, a teacher who displayed the Prophet Muhammad caricatures to students in freedom of speech class, was killed in a suburb north of Paris. On Friday evening, just days after he showed Charlie Hebdo's caricatures of Prophet Muhammad to the students, Copyright (C) GLOBAL ACADEMIC EXCELLENCE (M) SDN BHD - All rights reserved 


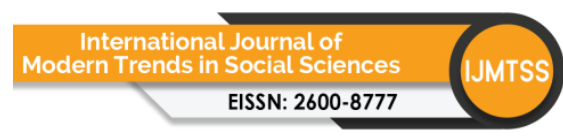

Volume 4 Issue 15 (March 2021) PP. 133-146

DOI 10.35631/IJMTSS.4150012

he was beheaded while walking home. A Chechen refugee that committed the attack, who was only 18 years old, was later fatally shot by the police (Cuthbertson, 2020).

After the killing of Samuel Paty, a wave of outrage spread through France, dozens of raids by the France police had been carried out aiming at the radical Islamist. The France government had pledged to expel foreign citizens that displayed radicalism signs and promised to cut off Muslim aid organizations (Shannon \& Levitt, 2020). Emmanuel Macron, the French president, declared Samuel Paty as an icon of France's strong democratic values and its denial of religious interference into the public domain. In the name of freedom of speech, along with the members of his government, Macron vowed to continue to support Prophet Muhammad caricatures portrayals (Nossiter, 2020).

Following Macron hostility towards Islam, other attacks occurred inside and outside France. On October 29 2020, in France, a Tunisian man armed with a knife attacked worshippers in a church in the Mediterranean city of Nice and killed three (A.P. News Wire, 2020). Meanwhile, on the same day, in another part of the world, a man was arrested after assaulting the guard outside France consulate in Saudi Arabia (Goddard, 2020).

The support towards the portrayal of Prophet Muhammad caricatures also had sparked anger to billions of Muslims worldwide. The Muslim world believed that it was impossible to justify freedom of speech that tarnished the sacredness, honour and holiness of religious values and symbols. Muslim countries such as Turkey, Indonesia, Bangladesh, and Pakistan protested and called for a boycott on France goods (Mahmud, 2020).

\section{Problem Statement}

A lot of problems emerged after the 2020 France attacks. The outraged of the France citizens that encouraged and supported by the French president himself had displayed hostility towards Muslims in France and also Muslims around the world. Even though the Western media had long known to feature Islam constantly in the negative light (Ishak \& Solihin, 2012), this incident had ignited more negative images of Islam. Again, Islam was projected as a symbol of terrorism, violence, extremism and radical in the Western media. Muslims were treated as enemies, be it in France or outside France (Nossiter, 2020).

Also, innocent Muslims in France were stigmatized and forced to deal with Islamophobia even though they had nothing to do with the attack incident (A.P. News Wire, 2020). The utmost disaster was that the Prophet's caricatures were projected onto government buildings in France. On December 21 2020, the controversial caricatures by Charlie Hebdo were shown onto town halls in Montpellier and Toulouse for hours (Cuthbertson, 2020). This action had absolutely insulted and outraged the Muslims worldwide, thus leading to the destroyed relationship between France and Muslim communities.

This study's major goal was to investigate how all these 2020 France attacks-related issues were portrayed in the media in the United Kingdom (U.K.) and United States (U.S.). This study aims to determine the dominant issues covered, the news slant, and the newspapers' tone and framing regarding the France attacks-related issues. Last but not least, this study also aims to compare the differences between the U.K. and U.S. media in reporting the France attacksrelated issues. 


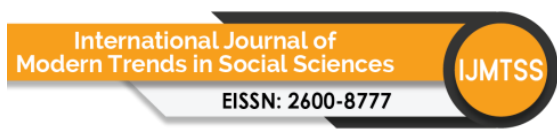

Volume 4 Issue 15 (March 2021) PP. 133-146 DOI 10.35631/IJMTSS.4150012

\section{Research Objectives}

1. To examine the dominant France attacks-related issues covered by the mainstream newspaper in the U.K. and U.S.

2. To understand the news slant of France attacks-related issues covered by the mainstream newspaper in the U.K. and U.S.

3. To explore the newspapers' tone and framing of France attacks-related issues covered by the mainstream newspaper in the U.K. and U.S.

\section{Significance of The Study}

This study crystallizes the representations of attacks in France, from the incident of Samuel Paty murder to the tragedy of public portrayal of the Prophet Muhammad caricatures, while simultaneously intending on identifying the way of these scenarios' coverage in the Western media. This study offers a clearer picture of the role of the news media in 'terror' incident, specifically when it involves Muslims. This study's significance manifests itself in its contribution to the Muslims and non-Muslim communities, and also towards the local and international news media management authorities, so that more balanced, objective and unbiased narratives could be provided in the future. Furthermore, this study might be beneficial and aid the existing literature on media framing. Scholars and researchers might also be benefited as this study could generate better insights into their understanding in this field and hence serve as a reference.

\section{Literature Review}

\section{The History of France Attacks due to Prophet Muhammad Cartoon Portrayal}

In February 2006, Charlie Hebdo, a controversial satiric magazine, published cartoons of Prophet Muhammad, the Prophet of Islam. The cartoons were originally from Danish JyllandsPosten but were reprinted by Charlie Hebdo. Following this incident, the Union of French Islamic Organizations and the Grand Mosque of Paris sued Charlie Hebdo under anti-racism laws because it was prohibited in Islam to make any Prophet's visual depictions. However, the French court held that Philippe Val, Charlie Hebdo's executive editor as not guilty. The court ruled that the one who was being ridiculed in the cartoons were not Muslims in general but only fundamentalists (Petrikowski, 2020).

Due to the court ruling that favoured the magazine, Charlie Hebdo kept publishing insulting Islamic contents. According to Mebtoul (2020), in 2011, the magazine then made a special edition entitled "Charia Hebdo" (in referring to Sharia law, the law of Islam) and named the editor in chief as Prophet Muhammad. The magazine mocked the Prophet of the Muslim by featuring Prophet Muhammad on the cover saying, "100 lashes if you do not die laughing!". This mocking publication led to disaster when the magazine's publication offices were bombed on November 22011 (Petrikowski, 2020).

France government and France court had never stop Charlie Hebdo from kept publishing the portrayal of Prophet Muhammad. As the consequences, four years later, on January 72015 , deadly violence attacks shook France when 17 people, including 11 journalists and security personnel were found dead at the offices of Charlie Hebdo in Paris (Schofield, 2020). Then, five years later, on October 16 2020, a high school teacher named Samuel Paty was beheaded after showing the Prophet Muhammad cartoon in his class. Not more than two weeks later, on October 29 2020, a stabbing spree occurred and killed three at a church in the Mediterranean city of Nice. 


\section{The Controversy between Freedom of Speech and Religion Sacredness}

Volume 4 Issue 15 (March 2021) PP. 133-146 DOI 10.35631/IJMTSS.4150012

In the name of freedom of speech, since the assassination of Samuel Paty, officials in France reinforced the right to portray Prophet Muhammad cartoons, and the cartoons were widely portrayed during the protests in France (Goddard,2020), and even displayed onto the government buildings in France (Cuthbertson, 2020). The French president also awarded the highest civilian honour to Paty, describing him as a "quiet hero" fighting for the freedom of speech (Cuthbertson, 2020).

The French president also emphasized that the country would never yield to anything even if France would be targeted again because of their beliefs in freedom of worship and freedom of speech. The Prophet Muhammad cartoons portrayal was strongly defended by Macron and other French officials as free speech (Onishi \& Méheut, 2020). Macron said in his statement "we will not give up caricatures and drawings, even if others back away" (Menezes, 2020).

However, in another part of the world, the Muslim communities, Muslim leaders, and even Muslim sports icon were condemning this type of free speech. The Indonesia President, Jokowi fiercely said that "freedom of expression that tarnishes the honour, sanctity and sacredness of religious values and symbols could not be justified and must be stopped. Linking religion with terrorist acts is a big mistake. Terrorism is terrorism, terrorists are terrorists, terrorism has nothing to do with any religion" (A.P. News Wire, 2020).

The undisputed Ultimate Fighting Championship (UFC) fighter, Khabib Nurmagomedov, also strongly condemned the act of French president. He strictly said in his social media posting that "May the Almighty disfigure the face of this creature (French president) and all its followers, who, under the slogan of freedom of speech, offend the feelings of more than one and a half billion Muslim believers. We are Muslims, we love our Prophet Muhammad (peace and blessings of Allah be upon him) more than our mothers, fathers, children, wives and all other people close to our hearts. Believe me, these provocations will come back to them, the end is always for the God-fearing" (Menezes, 2020).

\section{News Slant, Newspaper Tone and Newspaper Framing}

According to Pece (2018), as an information transmitter, mass media able to influence public attitude and behavior, especially regarding cultural and social context. One of the main reasons is because the mass media has the ability to influence public perception and expectation towards whatever being portrayed in it. Since ancient times, rulers have propagated their agenda by using the mass media (Hussain, 2014).

News slant, newspaper tone, and newspaper framing are among the essential elements in influencing the public. As stated by Entman (2010), news slant happens when a news story highlights the preferred context of one side when ignoring or derogating another side in a political dispute. Slanted news is one-sided framing that enhances certain aspects and eliminates others to allow recipients to focus on the evaluation characteristics that support the understanding of the preferred hand (Entman, 2010). Entman (2007) claimed that consistent slanted news of mediated communication which encourages the success of a certain party or ideology in government power contests will eventually became a content bias.

The news report contents are often distinguished by the news tone. As mentioned by Brunken (2006), news tone is also known as valence in framing literature, and it can be positive, neutral, or negative. According to De Vreese \& Boomgaarden (2003), if the principle of framing is 


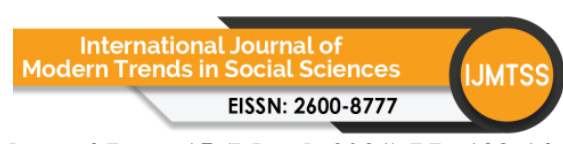

Volume 4 Issue 15 (March 2021) PP. 133-146 DOI 10.35631/IJMTSS.4150012

applied with the tone, it will be categorized that some frames will be 'good' and some frames will be 'bad' juxtaposition, and it will be set off to positive or negative tone implicitly or both. Several kinds of research indicated that news tone has several major effects on media coverage. News tone causes the public to think about a specific event in a certain way. Brunken (2006) emphasized that, it seems that in the case of a negative news tone, people are likely to be negative towards the matter.

In defining framing, Entman (2010) argued that framing consists of selecting some aspects and connecting them in a narrative that promotes a specific perception of perceived truth. There are many purposes of framing, including problem identification, cause specification, portray moral judgment, and giving solutions (Entman, 1993, 2004). Framing shapes and changes the meanings and expectations of audience members through priming. This means that the frames provide for or improve the availability of certain ideas for judging an event or scenario (McCombs \& Ghanem, 2001; Scheufele, 2000). Skillful framing implies guiding the perceived real-world reality, typically subject to different interpretations towards the journalists' assumptions and constructions. Even in a general election, a framing effect might affect two or three percent of public opinion (Entman, 2010).

Briefly, in dispersing news and information regarding crime, violence, and terrorism attack, the news slant, newspaper tone, and newspaper framing play a vital role. Nowadays, in the West media, violence committed by Muslims has been covered by 1.5 times more than nonMuslim violence on average, and Muslim thwarts have been covered five times more. The coverage will be more likely to identify Muslim attacks as "terrorism", and the Muslim perpetrators will be labelled along with their religion and ethnic identities (Kanji, 2018). Terror news appears in the media to be a major concern. However, as it appeared in the newsroom, the real debate of framing terrorism remains a discussion (Sukarno, 2011).

\section{Newspapers' Framing regarding the France Attacks}

On January 7 2015, the day of the attack at Charlie Hedbo's headquarters, the National Union of Journalists (NUJ) denounced that the shooting incident as "an attempt to assassinate the free press" (Nissim, 2015). According to Zogata (2015), after the assault on the headquarters of Charlie Hebdo, European news editorial staff determined to express their solidarity with the assassinated cartoonists. Hence, almost all of the news titles and headlines of the incident clearly framed it as a terrorist attack.

The Independent, a U.K. newspaper and $L^{\prime} E c h o$, a newspaper from the Limousin region of France, both published a bold message for the terrorists by drawing a middle finger along with a pen in their front pages. This indicated that they did not fear the attacks, and the attacks would never stop their freedom of expression. Then, a French sports magazine named L'Équipe also portrayed in its front page an illustration that described the attack as a contest between Liberte (freedom) and Barbarie (barbarity), and Barbarie already won 12 times (claimed 12 lives). Also, the Toronto Sun, a Canada newspaper portrayed in its front page the illustration of a hand, covered in bloodstain, trying to draw with a drawing brush named freedom (Mazza, 2015). Zogata (2015) claimed that almost all of the Western media framed the incidents of France attacks in 2015 as a narrative of spreading terrorism and the need to fight it. This study, however, intended to examine the way Western media framed the recent (2020) France attacks. 


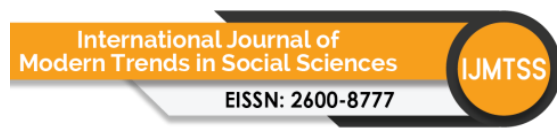

Volume 4 Issue 15 (March 2021) PP. 133-146 DOI 10.35631/IJMTSS.4150012

\section{Theoretical Framework}

This study was guided by framing theory that was founded by Erving Goffman. Goffman had introduced framing analysis in 1974, explaining that media chose on what events to give attention to and then positioned them within a field of meaning (Goffman, 1975). Framing theory explores how the media decided on what information the viewers would consume and how it was portrayed and represented. Framing is the act of deliberately pick and exclude stories, write stories based on the angle that the news worker wanted to while excluding other angles of stories that the news worker did not prefer, setting and frame the news agenda, and decide what the viewers see, hear and read (Fong \& Ishak, 2010).

Many scholars had used framing theory to study content analysis of newspapers related to Islam and Muslim-related issues (Manaf \& Sedu, 2015; Hassan, Azmi, \& Abubakar, 2017; Rahman \& Qamar, 2017). This current study also adopted framing theory to examine what kind of news related to the France-attacks that were selected and projected in the U.K. and U.S. media, and what kind of perceived reality and particular view that these media try to promote. Hence, guided by this theory, the dominant themes of the news, the news slant, the news tone and news framing of the France-attacks related issue were analyzed.

\section{Research Methodology}

The study's scope is going to cover about the 2020 France attacks, in which starting from the murder of Samuel Paty, the reason the murder happened, until the consequences of the murder that lead to more attacks and demonstration from both France and Muslims world.

This study is adopting both qualitative and quantitative content analysis. Content analysis is a method used to quantify and analyze the meanings within texts such as articles and newspapers by breaking down or coding the text into manageable categories or themes (Erlingsson \& Brysiewicz, 2017). The unit of analysis for this study was the issues that appeared in each article in the selected newspapers and the words and phrases that were used to describe them. This study was categorized according to the research objectives based on the news' dominant issues, news slant, news tone, and news framing. To get more detailed data, this research code three code for the dominant issues, which were Islamist 'terrorism' in France, Muslims Boycott towards France, and Islamist 'terrorism' outside France. This study also coded three code for the news slant, which were Pro-Islam, Against Islam and Balance. News tone and news framing also were analyzed based on the three issues.

Purposive sampling was adopted in this study to collect the data related to the France attacks. According to Dudovskiy (2020), purposive sampling is the technique of using own judgements to select data to be analyzed in the study. Purposive sampling is also a non-probability sample, in which the sample chosen in the study needs to have the same characteristics required in the research objective (Dudovskiy, 2020). Hence, by adopting purposive sampling, this study had wisely selected the research data that had the same characteristic, in which all of them were related to the France attacks incident. Purposive sampling aid to generate a suitable sample for this study. The samples of this study were The Independent and The New York Times. This study utilized data from news articles and feature articles collected from the two mainstream online daily newspapers, which were The Independent from the U.K. and The New York Times from the U.S.. These newspapers were chosen because of their high readership and circulation level, in which The Independent was among the top five the most popular newspaper in U.K. (Statista Research Department, 2020), while The New York Times was among top three most popular newspaper in U.S. (Agility, 2020). This indicated that these newspapers were the Copyright (C) GLOBAL ACADEMIC EXCELLENCE (M) SDN BHD - All rights reserved 


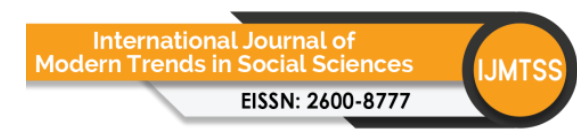

Volume 4 Issue 15 (March 2021) PP. 133-146

DOI 10.35631/IJMTSS.4150012

mediums that were most read by Britain and American, and were deemed to be the most significant source of information for them.

\section{Data Collection}

A systematic study about newspaper coverage of the recent France attacks in October 2020 was undertaken over a period of 30 days. The analysis was based on the France attacks-related news that appeared on the online version of the two online daily newspapers; one British newspaper and one American newspaper. The time frame of data collection is from October 16 until November 14, 2020. The time frame was selected based on the first day that the first attack happened, until a month after the attack. The selected news was based on what was thought to be related to the 2020 France attacks, the reason why the attacks happened, and the consequences of the attacks. Provided by this kind of data selection, the issues that were covered during this time frame were examined.

\section{Data Analysis}

This study's data were analyzed using basic descriptive analysis (quantitative) and thematic analysis (qualitative). Basic descriptive analysis is the process of transforming raw data by rearranging and manipulating it to become a form in which easier for the readers to interpret and understand, such as frequency table and proportion or percentage (Zikmund, 2003). Meanwhile, thematic analysis is the process of systematically exploring patterns across qualitative data by identifying, organizing, and offering insight into, and represent it by patterns of meaning (themes) that representing the different angle of a phenomenon (Clarke \& Braun, 2014).

This analysis focused on the details of France's attack-related issues, including the dominant themes, the news slant, and the tone and framing of information that prevailed in the selected news or feature articles. It is essential to mention here that this study's results could not be applied or generalized to other Western newspapers. The results only belong to the newspapers that had been selected in this study only, which were The Independent and The New York Times.

The news was coded into three themes: Islamist 'Terrorism' in France, Muslims Boycott towards France, and Islamist 'Terrorism' outside France. These themes were made based on the most frequent issues portrayed regarding the France attacks. There was a total of 56 articles on the France attacks-related issues reported by The Independent and The New York Times. The list of articles is shown in Table 1.

Table 1: Number of France Attacks-Related Issues

\begin{tabular}{cc}
\hline Newspaper & No. of Articles \\
\hline The Independent & 30 \\
The New York Times & 26 \\
Total & $\mathbf{5 6}$
\end{tabular}

\section{Findings and Discussion}

\section{Dominant Issues Related to the France Attacks}

Table 2 yielded that, Islamist 'Terrorism' in France was the most dominant issue in the two selected newspapers $(n=30)$, followed by Muslims Boycott towards France issue $(n=16)$, and Islamist 'Terrorism' outside France issue $(n=10)$. Furthermore, the data analysis also revealed that these two newspapers' importance was treated differently by these two newspapers. 


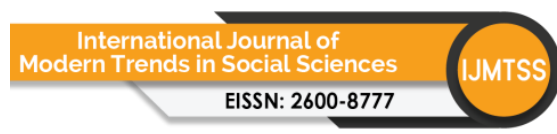

Volume 4 Issue 15 (March 2021) PP. 133-146 DOI 10.35631/IJMTSS.4150012

Islamist 'Terrorism' in France issue was covered more in The New York Times $(\mathrm{n}=17)$ compared to The Independent $(\mathrm{n}=13)$. Nevertheless, the differences were not significant. Hence, it could be said this issue coverage was quite balanced in both newspapers. It also could be concluded that both newspapers view Islamist 'terrorism' in France as the dominant issue in the 2020 France attacks.

It is important to note that the Western media had a long history of high coverage of Islamist terrorism. Therefore, it could safely be believed that the issue that would get the most coverage was about the association of terrorism with Muslims. This segment would discuss the most dominant issue, which was Islamist 'terrorism' in France.

Islamist 'terrorism' in France: Basically, there were two main events in 2020 France attacks, which were the beheaded of Samuel Paty and the shooting at a church in Nice that killed three. Both of these attacks were committed by Muslims, in respond of the insulting of Prophet Muhammad. Even though other brutal crimes also existed in France like murder and serial killings, since this act of killing was committed by Muslims, then it was a good reason for its frequent coverage of this issue. The involvement of Islamic elements was the selling point to report this issue. This could be seen in the following excerpt:

"He said the man, who was unknown to the French authorities, was arrested after lunging at police officers while yelling Allahu Akhbar." (Onishi \& Méheut, 2020).

"Armed only with a knife, he killed three people at the Notre-Dame basilica in Nice before lunging at police officers while yelling, Allahu Akhbar." (Onishi, Méheut, \& Foroudi, 2020)

"On his Facebook account, he posted a photo of himself posing with his new phone. A line above the photo read: 'Allah knows that we are not here for this mortal world'." (Onishi, Méheut, \& Foroudi, 2020)

Table 2: Coverage of France Attacks-Related Issues

\begin{tabular}{cccc}
\hline France attacks -related Issues & The Independent & The New York Times & Total \\
\hline Islamist 'Terrorism' in France & 13 & 17 & $\mathbf{3 0}$ \\
Muslims Boycott towards France & 14 & 2 & $\mathbf{1 6}$ \\
Islamist 'Terrorism' outside France & 3 & 7 & $\mathbf{1 0}$ \\
Total & $\mathbf{3 0}$ & $\mathbf{2 6}$ & $\mathbf{5 6}$ \\
\hline
\end{tabular}

Muslims Boycott towards France issue was the second-highest covered issue. However, the coverage was dramatically imbalance when the data revealed that this issue was covered significantly higher in U.K. newspaper as compared to U.S. newspaper. The newspapers coverage differences were huge in which, 14 articles were covered in The Independent while only two articles were covered in The New York Times. This highlights that newspaper in the U.S. did not give much coverage to the Muslims angriness and religion sensitivity towards the portrayal of Prophet Muhammad cartoon, as compared to the newspaper in U.K. This also shows that insulting the Muslims' belief does not matter in the U.S., only the act of 'terrorism' of the Muslims matter. In fact, this shows that in the U.S., the cause of the incident (Prophet cartoon portrayal) of the 'terrorism' was not important, the most important was the incident ('terrorism'). It also could be said that the U.S. newspaper covered more Islamist 'terrorism' 


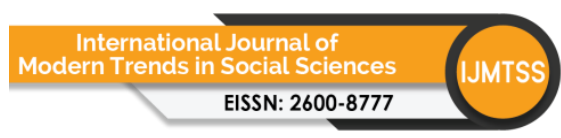

Volume 4 Issue 15 (March 2021) PP. 133-146 DOI 10.35631/IJMTSS.4150012

issue compared to the U.K. newspaper when the issue of Islamist 'terrorism' outside France also got more coverage in The New York Times $(\mathrm{n}=7)$ compared to The Independent $(\mathrm{n}=3)$.

In a nutshell, it could be concluded that the most dominant issue related to France attacks in both newspapers in the U.S. and U.K. was the Islamist 'terrorism' in France issue. However, to compare the number of coverages from the two newspapers, the analysis showed that U.S. newspapers covered more Islamist 'terrorism' news compared to the U.K. newspaper. The U.S. newspapers also lack coverage when it comes to disseminating news from the Muslims side or from the Muslims perspective compared to the U.K. newspaper. The data also revealed that the U.S. newspaper was imbalanced in covering issues related to France attacks when Islamist 'terrorism' in France issued a really high coverage $(n=17)$ while the Muslims Boycott towards France issue only got minimal coverage $(n=2)$. Meanwhile, The U.K. newspaper was almost balanced in reporting this issue when Islamist 'terrorism' in France issue ( $\mathrm{n}=13)$ got almost the same number as Muslims boycott towards France issue $(n=14)$.

\section{News Slant of France Attacks-related Issues}

Table 3 indicated remarkable differences in the France attacks-related issues coverage by the newspaper in the U.K. and the U.S. when it comes to describing Islam. The newspapers slant was categorized as to whether the articles related to France attacks were written in the context of pro-Islam, against Islam, or balance. The data revealed that The New York Times covered mostly the news against Islam (77\%), while The Independent covered mostly balance news $(60 \%)$ that neither sided with Islam nor France.

Table 3: Newspaper slant of France attacks-related issues

\begin{tabular}{ccc}
\hline Newspaper Slant & The Independent (\%) & The New York Times (\%) \\
\hline Pro-Islam & $33 \%$ & $8 \%$ \\
Against Islam & $7 \%$ & $77 \%$ \\
Balance & $60 \%$ & $15 \%$ \\
\hline
\end{tabular}

In comparing the news slant, the findings revealed that The Independent covered more proIslam (33\%) news than The New York Times (8\%). This highlights that the media in the U.S. did not favour Islam as there was very little news covered in favouring of Islam. This statement also could be justified when The New York Times highly covered news against Islam (77\%) while The Independent only covered $7 \%$ of news against Islam. When it comes to balance and unbiased reporting, the analysis showed that The Independent did a great job when $60 \%$ of the news coverage on France's attacks-related issues were balanced compared to only $15 \%$ of balance news in The New York Times.

Hence, it could be concluded that the media in the West could not be generalized since they had a different stand in reporting news or journalism. Media in the U.K. chose to write more balanced news when it comes to reporting about Islam while media in the U.S. inclined to be hostile towards Islam, especially when most of their news was against Islam. It also could be concluded that the media in the U.K. seemed to portrayed favourable disclosure of Islam when it succeeded writing 33\% news that was pro-Islam and only $7 \%$ news against Islam; even though there was a conflict of beheading incidents in relation with the France attacks-related issues. 


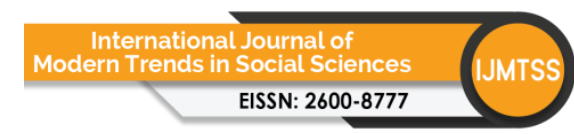

Volume 4 Issue 15 (March 2021) PP. 133-146

DOI 10.35631/IJMTSS.4150012

\section{Newspapers' Tone and Framing of France Attacks-related Issues}

In terms of newspapers' tone and framing, the two newspapers indeed were very different in reporting news related to the France attacks. When it comes to Islamist 'terrorism' in France issue, the U.K. newspaper reported in The Independent that the attack in French church as a 'gruesome' attack, while the act of portraying Prophet Muhammad cartoon was a 'mocking' act towards Muslims:

"A new suspect is in custody Friday in the investigation into a gruesome attack by a Tunisian man who killed three people in a French church, as France heightened its security alert amid religious and geopolitical tensions around cartoons mocking the Muslim prophet." (A.P. News Wire, 2020).

Nevertheless, in reporting the same issue, the U.S. newspaper reported in The New York Times with negative tone saying that the attack was a 'terror' attack, and the act of portraying Prophet Muhammad cartoon was a 'fight for freedom of speech':

"A terror attack that killed three people in Nice on Thursday left France increasingly embattled at home and abroad, as the government called for toughening measures against Islamist extremism, amid rising tensions with Muslim nations... Mr. Macron and other French officials fiercely defended the drawings as freedom of expression. The teacher who was beheaded had shown caricatures of the Prophet Muhammad in a class on secularism and free expression, angering some Muslims, including the 18-year-old man, a complete stranger, who sought him out and killed him." (Onishi \& Méheut, 2020).

Apart from that, in reporting the Muslims Boycott towards France issue, the U.K. media in The Independent framed quite a lot of articles featuring the voice of Islamic country leaders that protested towards France. The news' tone also gave justification on how the freedom of speech that inclined to insult others should never be allowed, and how the act of crime by some Muslims should not be the indicator to generalize all Muslims worldwide:

"Widodo said freedom of expression that tarnishes the honor, sanctity and sacredness of religious values and symbols could not be justified and must be stopped... "Linking religion with terrorist acts is a big mistake," Widodo said. "Terrorism is terrorism, terrorists are terrorists, terrorism has nothing to do with any religion." (A.P. News Wire, 2020).

Yet, in U.S. media, via The New York Times, the journalism of Muslims Boycott towards France issue was negatively framed. Despite the fact of lack of coverage of this Muslims protesting issue in The New York Times, the newspaper also framed the protest as an 'ugly turn' of the Muslims:

"President Emmanuel Macron, a fierce defender of French secularism and the right to free speech went as far as to suggest that Islam was in need of an Enlightenment, and his interior minister spoke of a "civil war." In the Muslim world, these actions, and the tone coming from top French officials, have opened France to criticism that the nation's complicated, post-colonial relationship with its six million Muslim citizens has taken an ugly turn." (Erlanger, 2020). 


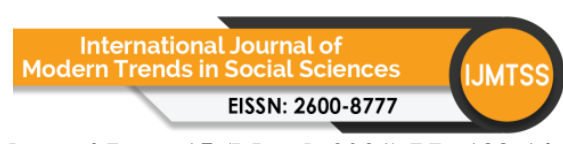

Volume 4 Issue 15 (March 2021) PP. 133-146 DOI 10.35631/IJMTSS.4150012

Last but not least, in framing the Islamist 'terrorism' outside France issue, in the scenario of the attacked guard outside the French consulate in Saudi Arabia, The Independent framed this incident without being biased and no negative tone. The Independent reported the word of "sharp tool" and "on maximum alert" with the double quotation marks (" "), and covered the whole incidents by informing that the guard life was not in danger:

"A Saudi man was arrested in Jeddah after attacking a guard with a "sharp tool" at the French consulate on Thursday, as France urged its citizens in the kingdom to be "on maximum alert". The French Embassy in Riyadh said the consulate was subject to an "attack by knife which targeted a guard", adding the guard was taken to hospital and his life was not in danger." (Goddard, 2020).

However, this kind of reporting did not apply in The New York Times when the newspaper covered on the same issue, yet the incident was framed on how Islam is highly related with terrorism throughout history, and the news tone was very negative. The New York Times also framed the incident to be empathetic towards France, but not relating the incidents as the consequences of France's insulting act of portraying Prophet Muhammad cartoon on the government buildings in France:

"France has been targeted repeatedly since the republication in September of Prophet Muhammad caricatures by the satirical newspaper Charlie Hebdo. France has since been targeted by a series of knife attacks, protests in Muslim nations and a call by some Muslim countries to boycott French goods." (Méheut, 2020).

In a nutshell, the findings of the study yielded that the tone and frame employed by the U.K. and U.S. newspapers were different. It could be concluded the U.K. journalists framed the news more balance and the news tone were more positively towards Islam, while the U.S. journalists' tone in the news was negative towards Islam and the frame of their news was dramatically imbalanced. This suggested The New York Times' underlying intention to never promote Islam as a religion of peace, or at least suggested the fear of the American towards the rising growth of Muslims worldwide.

\section{Conclusion}

As a conclusion, by adopting framing theory, this theory aided this study to reach its aims. The findings of this study revealed that the dominant issue related to the France attacks covered by The Independent and The New York Times was Islamist 'terrorism' in France. This study also found out that the news slant of both newspapers was significantly different. The Independent's news slant was balance towards both France and Islam, while The New York Times' news slant was against Islam. Last but not least, the news tone and framing of both newspapers were also different, in which The Independent news tone was not negative and the framing gave the views and perspectives from both France and the Muslim world. Meanwhile, The New York Times' news tone was negative and the framed of the news was more towards empathetic towards France and emphasizing the value of 'freedom of speech' of the France that urging the rights to insult other people religion.

\section{Biodata}

Nur Izzati Ariffin is a Master of Human Science in Communication graduate. She graduated from International Islamic University Malaysia (IIUM) Gombak, Selangor, Malaysia. Her 
research interests are in Journalism, Cultural Communication, Organizational Communication, Social Media, and Health Communication.

Dr. Faridah Hussain is a Senior Lecturer at the Faculty of Law, Universiti Teknologi MARA (UiTM), Shah Alam, Selangor. She obtained her Ph.D. from International Islamic University Malaysia (IIUM) specializing in Privileged Wills. Her research interests are in Probate and Administration of Estate, Civil Trial and Advocacy, Civil Procedure, Ethics of the Legal Profession, Business Law, Environmental Law, Media Law, and Journalism.

\section{References}

Agility. (2020, September 09). Top 10 U.S. newspapers by circulation. Retrieved December 19, 2020, from https://www.agilitypr.com/resources/top-media-outlets/top-10-dailyamerican-newspapers/

A.P. News Wire. (2020, November 6). Horrified by deadly attacks, France Muslims protect church. The Independent. Retrieved December 18, 2020, from https://www.independent.co.uk/news/horrified-by-deadly-attacks-France-muslimsprotect-church-muslims-muslim-France-ap-church-b1637091.html

A.P. News Wire. (2020, October 31). Indonesian leader condemns France attacks, Macron's comments. The Independent. Retrieved December 19, 2020, from https://www.independent.co.uk/news/world/europe/indonesian-leader-condemnsfrance-attacks-macrons-comments-joko-widodo-emmanuel-macron-francecommunity-teacher-b1476296.html

Brunken, B. L. (2006). Hurricane Katrina: A content analysis of media framing, attribute agenda setting, and tone of government response (Doctoral dissertation, Faculty of the Louisiana State University and Agricultural and Mechanical College in partial fulfillment of the requirements for the degree of Master of Mass Communication in The Manship School of Mass Communication by Brigette Lynn Brunken BA, Louisiana State University).

Clarke, V., \& Braun, V. (2014). Thematic analysis. Encyclopedia of Critical Psychology, 19471952. doi:10.1007/978-1-4614-5583-7_311

Cuthbertson, A. (2020, October 23). Charlie Hebdo Muhammad cartoons projected onto government buildings in defiance of Islamist terrorists. The Independent. Retrieved December 18, 2020, from https://www.independent.co.uk/news/world/europe/charliehebdo-cartoons-muhammad-samuel-paty-teacher-france-b1224820.html

Dudovskiy, J. (2020). Purposive sampling. Retrieved August 01, 2020, from https://researchmethodology.net/sampling-in-primary-data-collection/purposive-sampling/

Entman, R. M. (2004). Projections of Power: Framing News, Public Opinion, and U.S. Foreign Policy. Chicago, IL: University of Chicago Press.

Entman, R. M. (2007). Framing bias: Media in the distribution of power. Journal of Communication, 57(1), 163-73.

Entman, R. M. (2010). Media framing biases and political power: Explaining slant in news of campaign 2008. Journalism, 11(4), 389-408. doi:10.1177/1464884910367587

Erlingsson, C., \& Brysiewicz, P. (2017). A hands-on guide to doing content analysis. African Journal of Emergency Medicine, 7(3), 93-99. doi:10.1016/j.afjem.2017.08.001

Fong, Y. L., \& Ishak, M. S. A. (2010). Covering religious conflict in Malaysia: How Sin Chew Daily framed the Lina Joy controversy. Jurnal Pengajian Media Malaysia, 12(2), 11 22. Retrieved December 4, 2020, from https://expert.taylors.edu.my/file/rems/publication/100268_572_1.pdf 
Goddard, E. (2020, October 29). Man arrested outside French consulate in Saudi Arabia after attacking guard. The Independent. Retrieved December 19, 2020, from https://www.independent.co.uk/news/world/middle-east/saudi-arabia-franceconsulate-attack-guard-jeddah-b1420321.html

Goffman, E. (1975). Frame analysis: An essay on the organization of experience. Cambridge Mass., New York: Harvard University Press.

Hassan, I., Azmi, M. N., \& Abubakar, U. I. (2017). Framing Islam in news reporting: A comparative content analysis. Asian Social Science, 13(10), 112. doi:10.5539/ass.v13n10p112

Hussain, S. (2014). Reporting on terror: Why are the voices of peace unheard? Conflict \& Communication Online, 13(2), 1-10.

Ishak, M. S., \& Solihin, S. M. (2012). Islam and Media. Asian Social Science, 8(7). doi:10.5539/ass.v8n7p263

Kanji, A. (2018). Framing Muslims in the "war on Terror": Representations of Ideological violence by Muslim versus Non-Muslim perpetrators in Canadian national news media. Religions, 9(9), 274, 1-26. doi:10.3390/re19090274

Mahmud, F. (2020, November 5). Why is Bangladesh protesting against France? Al-Jazeera. Retrieved December 19, 2020, from https://www.aljazeera.com/news/2020/11/5/whatprompted-the-prolonged-anti-france-protest-in-bangladesh

Manaf, A. M. A., \& Sedu, N. (2015). Framing Islam-related issues during GE13: An analysis of Malaysian mainstream newspapers. Intellectual Discourse, 23(1), 29-52.

Mazza, E. (2015, July 1). Newspapers react to Charlie Hebdo attack with show of solidarity on front pages. The Huffington Post. Retrieved December 21, 2020, from https://www.huffpost.com/entry/charlie-hebdo-front-pages_n_6433722

McCombs, M., \& Ghanem, S. I. (2001) The convergence of agenda setting and framing. In: Reese SD, Gandy O, and Grant AE, Framing Public Life (pp. 67-82). Mahwah, NJ: Lawrence Erlbaum.

Mebtoul, T. (2020, September 26). Paris knife attack: Suspect confesses, says Charlie Hebdo was target. Morocco World News. Retrieved December 21, 2020, from https://www.moroccoworldnews.com/2020/09/320851/paris-knife-attack-suspectconfesses-says-charlie-hebdo-was-target/

Menezes, J. D. (2020, October 30). Khabib attacks Macron over Islam comments: 'May the Almighty disfigure the face of this creature'. The Independent. Retrieved December 22, 2020, from https://www.independent.co.uk/sport/general/mma/khabib-instagramemmanuel-macron-islam-protests-latestb1447229.html?utm_source=taboola\&utm_medium=Feed

Nissim, M. (2015, January 7). Paris killings 'are attack on free press'. Retrieved December 21, 2020, from https://www.digitalspy.com/media/a619921/charlie-hebdo-killings-areattempt-to-assassinate-free-press-says-nuj/

Nossiter, A. (2020, October 19). After teacher's decapitation, France unleashes a broad crackdown on 'the enemy within'. The New York Times. Retrieved December 18, 2020, from https://www.nytimes.com/2020/10/19/world/europe/france-raids-teacherbeheading.html? searchResultPosition $=53$

Onishi, N., \& Méheut, C. (2020, October 29). New terror attacks leave France embattled at home and abroad. The New York Times. Retrieved December 22, 2020, from https://www.nytimes.com/2020/10/29/world/europe/nice-attack-

france.html?searchResultPosition $=15$ 
Onishi, N., Méheut, C., \& Foroudi, L. (2020, November 6). Attacks in France point to a threat beyond extremist networks. The New York Times. Retrieved December 22, 2020, from https://www.nytimes.com/2020/11/06/world/europe/france-attacks-beheadingterrorism.html?searchResultPosition $=15$

Pece, E. (2018). The representation of terror and moral panics: The media frames of the European press. Journal of Mediterranean Knowledge, 3(1), 87-99. doi: 10.26409/2018JMK3.1.06

Petrikowski, N. P. (2020). Charlie Hebdo shooting. Retrieved December 21, 2020, from https://www.britannica.com/event/Charlie-Hebdo-shooting

Rahman, S., \& Qamar, D. A. (2017). Islamophobia and Media: The framing of Muslims and Islam in international media. Journal of Peace, Development \& Communication ISSUE02, 01(02). doi:10.36968/jpdc.2017.i02.03

Scheufele, D. A. (2000). Agenda-setting, priming, and framing revisited: Another look at cognitive effects of political communication. Mass Communication and Society, $3(2 \& 3), 297-316$.

Schofield, H. (2020, September 2). Charlie Hebdo: 14 suspects on trial over Paris massacre. BBC News. Retrieved December 21, 2020, from https://www.bbc.com/news/worldeurope-53975350

Shannon, V., \& Levitt, J. (2020, October 19). Briefing: A wave of anger swept over France. The New York Times. Retrieved December 19, 2020, from https://www.nytimes.com/2020/10/19/briefing/fauci-voter-registrationimmigration.html?searchResultPosition $=50$

Sukarno, A. W. (2011). Dilema peliputan terorisme dan pergeseran pola framing berita terorisme di media massa. Jurnal Ilmu Sosial Dan Ilmu Politik, 14(3), 333-348. doi:https://doi.org/10.22146/jsp.10932

Statista Research Department. (2020, October 09). U.K.: Most popular newspapers 2019. Retrieved December 19, 2020, from https://www.statista.com/statistics/246077/reachof-selected-national-newspapers-in-the-uk/

Vreese, C. D., \& Boomgaarden, H. (2003). Valenced news frames and public support for the EU. Communications, 28(4), 361-381.

Zogata, I. W. (2015). The story of Charlie Hebdo: An analysis of European and American newspapers. Mediterranean Journal of Social Sciences, 6(2), 5th ser., 353-362. doi:10.5901/mjss.2015.v6n2s5p353hin, J. L. (2011). Women and Leadership: Transforming Visions and Current Contexts. Forum on Public Policy: A Journal of the Oxford Round Table, (2), 1-12. 